\title{
Das inter-relações entre obra terminográfica, tema e público-alvo: elaborando a árvore de domínio de um vocabulário de Culinária para tradutores
}

\section{Interrelationships between technical dictionaries, subject area and target audience: developing the domain tree for a Culinary dictionary for translators}

Elisa Duarte Teixeira*

\begin{abstract}
RESUMO: O presente trabalho visa discutir as implicações da escolha de um público-alvo específico - o tradutor - para o fazer terminológico de uma subárea específica: a Culinária. Após uma breve introdução à problemática discutida no artigo, os pressupostos teóricos do trabalho são apresentados e contrastados, com vistas a destacar sua relevância na metodologia de trabalho empregada. $\mathrm{O}$ estudo foca nas subclasses semânticas dos Ingredientes e, a partir da árvore de domínio proposta, fazemos uma análise das definições e conceitos do campo semântico "tempero(s)". Os resultados apontam para a necessidade de se considerar, em vez das categorias clássicas comumente usadas para separar os semas genéricos dos específicos (definidos dicotomicamente como positivos ou negativos), uma estruturação sêmica de periferia fluida e permeável, representando um continuum de sentido que vai do mais prototípico (núcleo) ao menos prototípico (margens) - considerando-se numa dada área de éspecialidade e levando-se em conta um público-alvo específico.
\end{abstract}

PALAVRAS-CHAVE: Terminologia. Terminografia. Culinária. Árvore de domínio. Classes semânticas.

\begin{abstract}
This paper discusses the implications of choosing a specific target audience - the translator - to the terminological work in a specific area of knowledge: cooking. After a brief introduction to the problem discussed in the article, the theoretical models used in our research are presented and contrasted, in order to highlight their relevance for the methodology used in this work. The analysis focuses on the semantic subclasses of the ingredients. Departing from the proposed domain tree, we analyze the definitions and concepts of the semantic field "tempero(s)" (seasonings). The resulting data points out to the need of considering, instead of the classic categories commonly used to separate generic traits from specific (defined dichotomically as positive or negative), a semic structure that is fluid and permeable on its periphery, representing a continuum of meaning that goes from the most prototypical (core) semic traits to the least prototypical (margins) - on a given area of expertise and taking into account a specific target audience.
\end{abstract}

KEYWORDS: Terminology. Terminography. Cooking. Domain tree. Definition. Semantic categories.

\section{Introdução}

"Mais precisamente, a questão em terminologia não é tanto saber o que significa a forma linguística, mas antes saber qual a forma linguística que representa uma dada noção" (DESMET, 1990)

\footnotetext{
* Doutora em Estudos Linguísticos e Literários em Inglês pelo Departamento de Letras Modernas da Faculdade de Filosofia, Letras e Ciências Humandas da Universidade de São Paulo. Tradutora e pesquisadora independente.
} 
Embora a tradução - entendida como exercício de comunicação entre povos de línguas distintas - seja muito antiga, a Terminologia, empregada no estudo descritivo e sistematizador dos vocabulários das línguas de especialidade, é uma área de pesquisa relativamente recente. Ainda assim, pode-se afirmar que, na prática tradutória atual, especialmente em sua modalidade técnica, tornou-se indispensável o uso de vocabulários / glossários técnicos, já que os dicionários de língua geral, enquanto decodificadores de unidades lexicais no nível de Sistema (COSERIU, 1967, p. 95), não têm como preocupação principal dar conta deste processo constante de nomeação de conceitos e práticas que ocorre nos diversos setores de atividade humana, profissionais ou não, através do qual criam-se hábitos linguísticos próprios, informalmente denominados "jargões".

Considerando-se a citação de Desmet acima e, ainda, as palavras de Barbosa (1990): "a tarefa básica da Terminologia é de nomear, preenchendo, pois, uma função de codificação e colocando-se questões do tipo: como nomear tal "fato"? como designar a operação que consiste em...?", parece claro que, em se tratando da pesquisa terminológica de uma dada área técnicocientífica ou de especialidade, o primeiro passo a ser dado é definir quais seriam essas "noções", "fatos" e/ou "operações" distintivas em tal área. Mas é justamente nesse ponto que as especificidades de cada área e do público-alvo a que a obra terminográfica se destina começam a impor-se ao terminólogo.

Tomemos por exemplo a Culinária - um saber até muito recentemente menosprezado enquanto área técnica, mas cujo volume de informações disponíveis vem crescendo significativamente. A recente internacionalização de ingredientes, produtos e, por consequência, de receitas e materiais sobre Culinária das últimas décadas demanda um tratamento terminológico adequado ao tema, haja vista a profusão de traduções e versões praticadas na área - sejam os textos receitas, rótulos de produtos importados, sites, revistas, programas televisivos, etc. Selecionar um público-alvo tão específico e especializado - o tradutor - trará consequências metodológicas e práticas para a obra terminográfica, oriundas de um tratamento diferenciado dos termos que considere as necessidades suscitadas pela tarefa tradutória.

A produção de obras terminológicas em língua portuguesa (e mais especificamente, no português brasileiro) cresceu muito nas últimas décadas, mas ainda é modesta e, na maioria das vezes, centrada em práticas mais valorizadas economicamente ou socialmente reconhecidas como, por exemplo, a Economia e o Direito, como apontou Aubert (1996). Propomos, neste 
artigo, colaborar com uma discussão sobre a tipologia e as relações entre os campos conceituais, lexicais e semânticos, partindo das relações entre o sistema conceptual e o sistema linguístico e chegando aos conjuntos e subconjuntos de termos da área de especialidade "Culinária" - mais especificamente os Temperos - caracterizando-os quanto à sua procedência, formação e perfil morfo-sintático-semântico. Essa tarefa será executada, desde o princípio, levando em conta o público-alvo escolhido - o tradutor -, atentando sempre para as implicações teóricas e formais dessa escolha para a obra terminográfica.

Vamos proceder inicialmente a uma discussão acerca do que seria uma árvore de domínio adequada ao tema e ao público-alvo aqui focalizados, partindo em seguida para a delimitação das classes semânticas pertinentes a essa árvore de domínio e, por fim, nos concentraremos apenas em uma dessas subcategorias - os Temperos -, procurando caracterizar alguns dos termos-chave da área, a saber: o próprio termo "tempero", "condimento", “especiaria", "erva(s)", "corante(s)", "aromatizante" e "flavorizante(s)".

\section{Pressupostos teóricos}

\subsection{Definindo as classes semânticas pertinentes ao tema: possibilidades}

O primeiro passo a ser dado pelo terminólogo, tão logo tenha se inteirado do assunto que será seu objeto de estudo e coletado algum material de consulta inicial, é proceder à elaboração da árvore de domínio ou grade conceptual da área. "Por árvore de domínio (do francês, arbre de domaine, vide Dubuc, 1985), entende-se um esquema que defina, ordenadamente, a área, a subárea e o tema da pesquisa a ser empreendida” (AUBERT, 1996). O mesmo autor observa que, nos casos em que a relação entre os traços semânticos pertinentes é mais complexa, torna-se útil o uso de "grades conceptuais", que comportam mais subdivisões e inter-relações que a estrutura de arborescência.

Para que se possa elaborar essa árvore de domínio / grade conceptual é necessário que se delimite primeiramente o campo semântico a ser abordado. Esse processo é necessário para que obra terminológica não corra "o risco do 'ruído' e o risco do silêncio" (AUBERT, op. cit.), ou seja, para que não se incluam termos que não são pertinentes à área (como por exemplo, incluir o termo "adubo" num glossário de Ervas) e nem tampouco se omitam termos fundamentais (como omitir "madeira” em um glossário de Marcenaria).

No entanto, no caso específico da Culinária, os textos de que dispomos, e que serão o ponto de partida para a determinação desse campo semântico, são todos voltados para o 
especialista da área, ou seja, são instrumentais, no sentido de corresponderem a uma representação "denotativa" daqueles processos, insumos, operadores, produtos e equipamentos envolvidos no fazer culinário. Da mesma forma, os glossários de Culinária disponíveis atualmente no mercado brasileiro buscam abarcar o "conjunto de marcas lexicais, sintáticas, estilísticas e discursivas que tipificam o uso de um código linguístico em ambientes de interação social centrados em uma determinada atividade humana" (AUBERT, 1996, p. 27). Buscam considerar, em primeira instância, a situação de uso do termo, seja em sua realidade prémoldada linguística e antropologicamente, seja em sua prática linguística diária entre os usuários da língua de especialidade em questão, considerando ainda as eventuais disparidades "lógicas", marcas culturais, regionais, socioletais, suas idiossincrasias, reduplicações sinonímicas, as relações hierárquicas entre seus diversos usuários, etc. Nesse caso, o objeto de estudo do terminólogo, como afirmado anteriormente, é a prática culinária em si.

Ora, no caso específico em que o público-alvo da obra terminológica é o tradutor, os processos, insumos, operadores, produtos e equipamentos per se não terão tanto interesse; ao contrário, a única realidade de análise manifesta, no caso, será o Discurso Culinário e o tratamento linear e sequenciado que o código linguístico dá àqueles elementos, bem como as relações de identidade, transitividade, disjunção e inclusão entre eles que daí decorrem. Portanto, procuraremos tratar a Culinária não como conjunto de fatos, mas como um conjunto de signos-objeto (discurso culinário) que já sofreram um recorte e perdas quando da sua codificação; ou seja, procuraremos fazer com que todos os critérios que se utilizem na elaboração dos modelos desta pesquisa baseiem-se tão somente no Discurso Culinário e não em sua natureza fenomenológica.

Justificamos essa escolha pelo fato de estarmos elaborando um glossário para o tradutor, que está interessado nas inter-relações entre os elementos do discurso culinário e não necessariamente na relação destes com a realidade prática culinária propriamente dita. De fato, o tradutor não precisa ser (e com frequência não o é) um especialista em Culinária para traduzir receitas e materiais da área. Todavia, precisa entender muito bem as relações que os termos estabelecem entre si, com as diversas partes do texto fonte e com outros textos da área dessa mesma língua de partida, e qual sua equivalência na língua de chegada, de forma que possa produzir um texto idiomático e que, ainda assim, reflita uma realidade fenomenológica para o leitor/usuário "especialista em Culinária".

Considerando, com Saussure, que "é o ponto de vista que cria o objeto", podemos assim 
esquematizar, inicialmente, o enfoque pretendido de nosso objeto de estudo material Culinária:

Universo dos Códigos

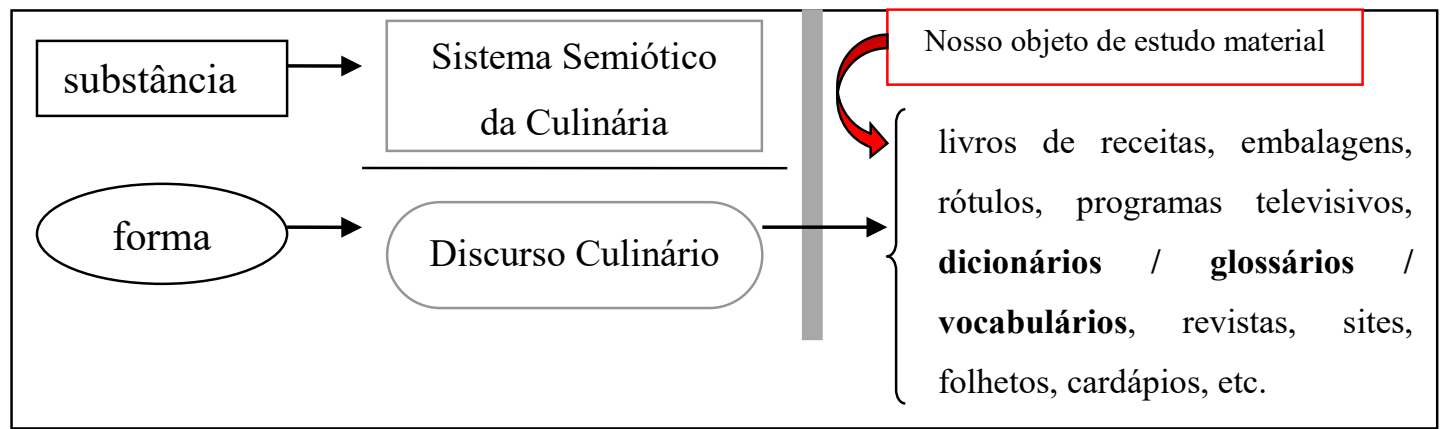

Figura 1. Elaboração do autor.

\section{Universo das Ciências da Linguagem}

Como é possível observar na Figura 1, os glossários, dicionários e vocabulários da área - que, por sua vez, têm como objeto de estudo a "fenomenologia culinária" - constituem, também, parte do corpus de nosso objeto de estudo.

Quanto ao recorte que empregaremos e que gerará, por conseguinte, nosso Objeto Formal, consideraremos a Culinária enquanto parte do Universo das Ciências da Linguagem do seu discurso - e não enquanto Sistema de Significação não-Verbal. A Culinária, por todas as suas implicações e correlações culturais, sociais, econômicas e biológicas, constitui um objeto de estudo material complexo. Se, por um lado, consideramos com Saussure, que os textos que compõem o discurso do fazer e do saber culinários seriam apenas uma parte do que se poderia considerar uma Macro-semiótica Culinária (vide Figura 2), parece também bastante razoável considerar, com Barthes (1971), que as receitas e todo o discurso culinário constituem o Sistema de Significação Primário que transcodifica a Semiologia Culinária, englobando-a, portanto (vide Figura 3).

\section{Saussure}

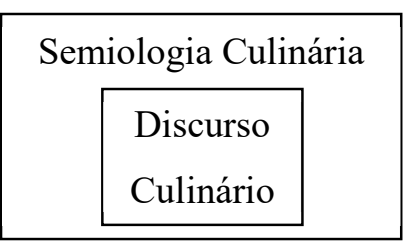

Figura 2

\section{Barthes}

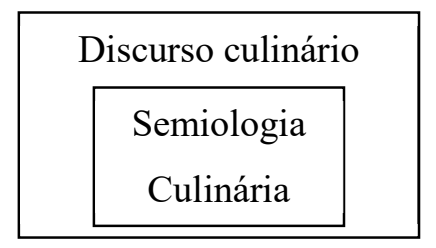

Figura 3

Com isso não queremos dizer que o Discurso Culinário consiga dar conta de todos os 
sentidos contidos na Semiologia Culinária. A complexidade dessa área é tal que não seria difícil imaginar e aplicar praticamente todos os modelos descritivos estruturais do sistema de significação verbal à Culinária e ainda assim não se dar conta de sua totalidade significativa. A alimentação é tão indissociável do ser humano quanto a linguagem, e ainda a precede, no sentido de que é mais essencial ao homem que esta. Trata-se efetivamente de um Sistema Semiótico comparável, em importância e comportamento, ao Linguístico.

Usando as palavras de Barthes (1971, p. 18) com relação à linguagem, poderíamos dizer que a Culinária "resiste às mudanças do indivíduo sozinho"; assim como as palavras, os ingredientes têm suas redes combinatórias e, tudo o que foge à norma culinária de uma comunidade (de uma região, de uma camada social, etc.) transforma-se em um desvio (combinar arroz com feijão no Brasil, por exemplo, é a norma - nos Estados Unidos, a combinação é considerada 'exótica'), bem como aquelas que fogem totalmente à norma (comer sopa de feijão com calda de chocolate, por exemplo) constituem o non sense. Na preparação dos alimentos, segue-se sempre uma rotina, e essa rotina compreende a seleção dos ingredientes, os processos empregados na preparação e os produtos finais que daí resultam - o que vai, efetivamente, ser degustado / ingerido. Ainda, dentro dos ingredientes, há sempre aquele(s) que será(ão) a base do prato e, na maioria das vezes, aquele(s) que o(s) complementará(ão); dentre os processos, sempre haverá uma preparação do(s) ingrediente(s) para o uso, sua transformação - geralmente por meio do calor - e a finalização / decoração / apresentação do prato (trataremos dessas questões mais à frente quando propusermos o modelo de análise de nosso objeto de estudo - as receitas).

Seguindo esse raciocínio, a Gastronomia, por sua vez, seria para a Semiótica Culinária o que a Literatura é para a Semiótica Linguística - as possibilidades combinatórias de alimentos e os sentidos $/$ produtos que são capazes de produzir, são ilimitados e, muitas vezes, não coincidem com aqueles tacitamente aceitos pela norma (um chef que decide criar uma receita de javali com molho de chocolate, por exemplo, pode estar buscando "quebrar" as regras da norma culinária em voga, surtindo assim um efeito 'estilístico' ou 'artístico', que ultrapassa o senso comum) - por isso é possível afirmar que a culinária, assim como a Língua, é Histórica, no sentido dado por Coseriu (1980, p. 91). Mas, deixemos de lado essa discussão por hora, pois é tarefa da Semiótica aprofundar esses estudos.

Para o propósito do trabalho em que o presente estudo se insere, qual seja, elaborar um glossário bilíngue cujo público-alvo é, a priori, o tradutor, escolhemos privilegiar o modelo de 
Barthes (Figura 2), pois, embora possamos concordar com Saussure - o Discurso Culinário é apenas um componente da Semiologia Culinária e de todos os Sistemas de Significação que a compõem - aqui, nos interessará dessa Semiologia apenas o que é apreendido pelo Sistema de Significação Verbal da Culinária, que, nesse sentido, perpassa e transcodifica todo o conjunto de sistemas significativos que compõem essa 'Macro-semiótica Culinária'. Tanto nossa árvore de domínio quanto nossos modelos de campos semânticos, lexicais e conceituais pautar-se-ão pela apreensão da "realidade culinária" do ponto de vista textual. Nosso modelo privilegiará, para tanto, uma parte dessa expressão textual - apenas as receitas culinárias (tipo textual que se destaca nas traduções da área), em todas as suas formas possíveis (vide Figura 4).

\section{Tipos discursivos da culinária}

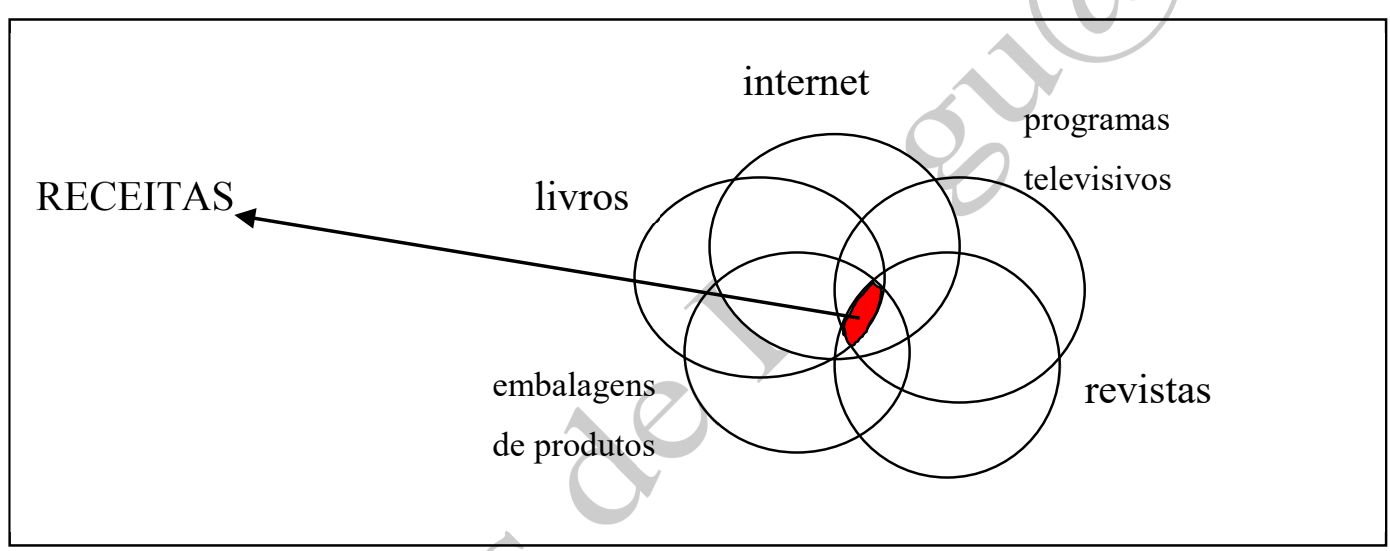

Figura 4. Elaboração do autor.

\section{Metodologia}

\section{1 Árvore de domínio: a receita como ponto de partida}

Quando começamos a pesquisar os possíveis materiais que nos serviriam de apoio na delimitação da árvore de domínio, decidimos pelos textos da Nutrição, uma vez que partíamos do pressuposto de que a Culinária é parte da Nutrição, dentro de um quadro das ciências naturais e biológicas. Se estivéssemos certos, nossa árvore de domínio seria algo como o que se vê na Figura 5: 


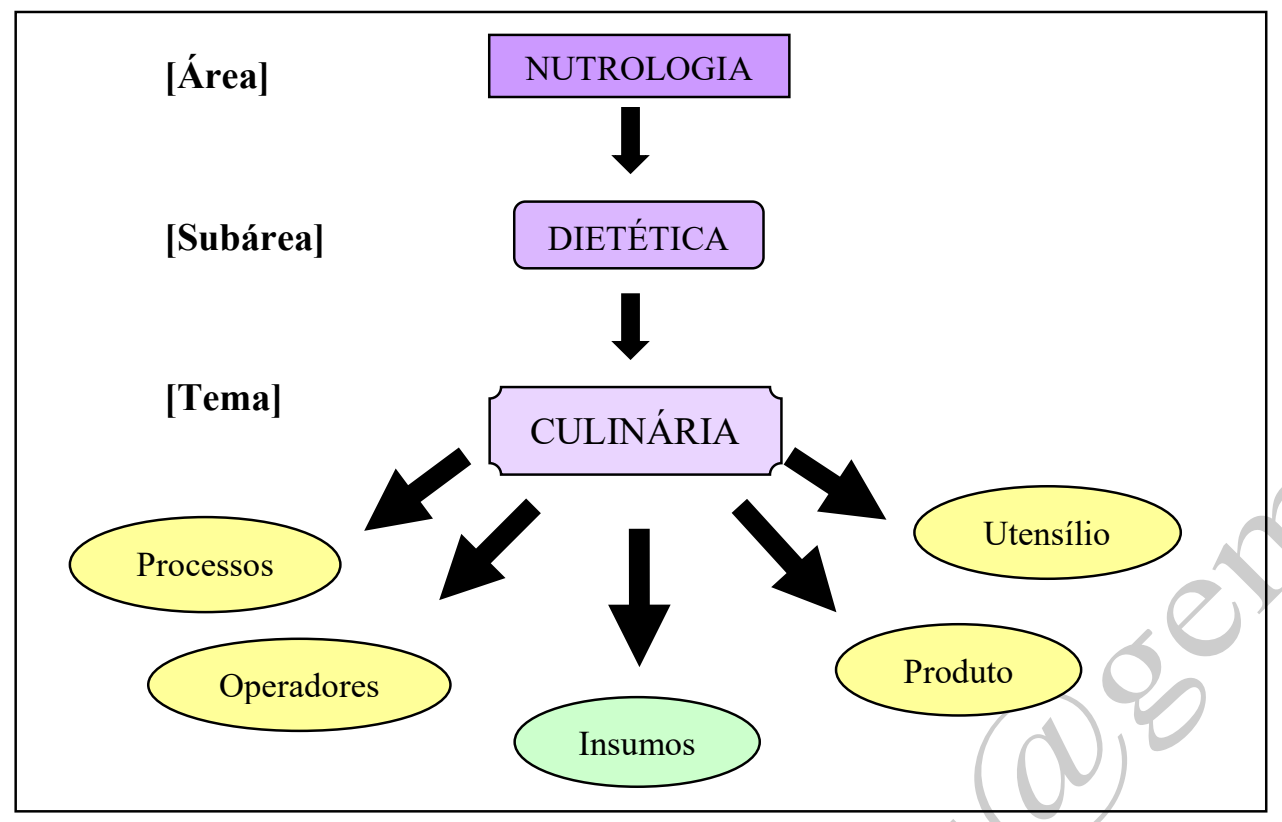

Figura 5. Elaboração do autor.

No entanto, um primeiro problema foi imediatamente identificado. Se considerarmos, com Aubert (id., ibid.), que essa árvore de domínio vai ser a "pedra de toque" para acrescentarmos ou excluirmos um termo de nosso glossário, será muitas vezes problemático, por exemplo, decidir se se está diante de um Insumo ou de um Produto, uma vez que muitos "produtos" são usados como "insumos" em outras receitas. Consideremos, por exemplo, o "curry", uma mistura de diversos temperos - entraria como Insumo (ingrediente) ou como Produto? E o que dizer do "arroz", no caso de uma receita de "bolinho de arroz" - em que o mesmo, já preparado (Produto), torna-se o Insumo, base de uma nova preparação? Outro ponto desfavorável é a categoria Operadores que, a não ser que nosso interesse estivesse voltado para a cozinha industrial e profissional em especial, não teria muita utilidade.

Porém, o aspecto que mais nos chamou a atenção e que foi decisivo para que mudássemos nossa perspectiva com relação ao enfoque a ser dado por nossa árvore de domínio é o fato de que esse modelo exposto na Figura 5, na verdade, busca categorizar e subdividir os fatos fenomenológicos da culinária em sua realidade de uso, e nossa pesquisa, como já afirmamos anteriormente, pretende pautar-se pela realidade linguística e não factual da culinária. Assim, nos materiais de Nutrição consultados encontramos definições e subdivisões dos alimentos com base nas suas características físico-químicas e biológicas e não - como é de nosso interesse - com base em suas diferenças semânticas e sintáticas, o que, em última análise, é a informação que o tradutor necessita. 
Ademais, o material da área de Nutrição consultado apresenta discrepâncias, possivelmente reveladoras de dificuldades, no tratamento dos temperos - que é o campo semântico do qual nos ocuparemos e que usaremos como exemplo em nossas análises. O livro Ciências Nutricionais ${ }^{1}$ faz uma divisão em que os temperos, ervas e especiarias não comparecem em forma de categoria, mas estão diluídos em categorias como a das hortaliças, dos grãos e das frutas secas. A divisão apresentada nessa obra é um tanto confusa, uma vez que "leguminosas" aparece encabeçando duas categorias diferentes (vide Quadro 1) e "ovos" foram colocados ao lado de "carnes", enquanto que "aves" formam uma categoria à parte:

Quadro 1.

\begin{tabular}{|ll|}
\hline$*$ frutas frescas & $*$ frutas secas \\
$*$ aves & $*$ crustáceos, tartarugas, mariscos e peixes \\
$*$ carnes e ovos & $*$ hortaliças, leguminosas e tubérculos \\
$*$ grãos e leguminosas & \\
\hline
\end{tabular}

Elaboração do autor.

Uma segunda obra consultada - Fundamentos de tecnologia de alimentos ${ }^{2}$ - apresenta um agrupamento das “matérias-primas da indústria alimentar" da perspectiva da Tecnologia de alimentos (vide Figura 6):

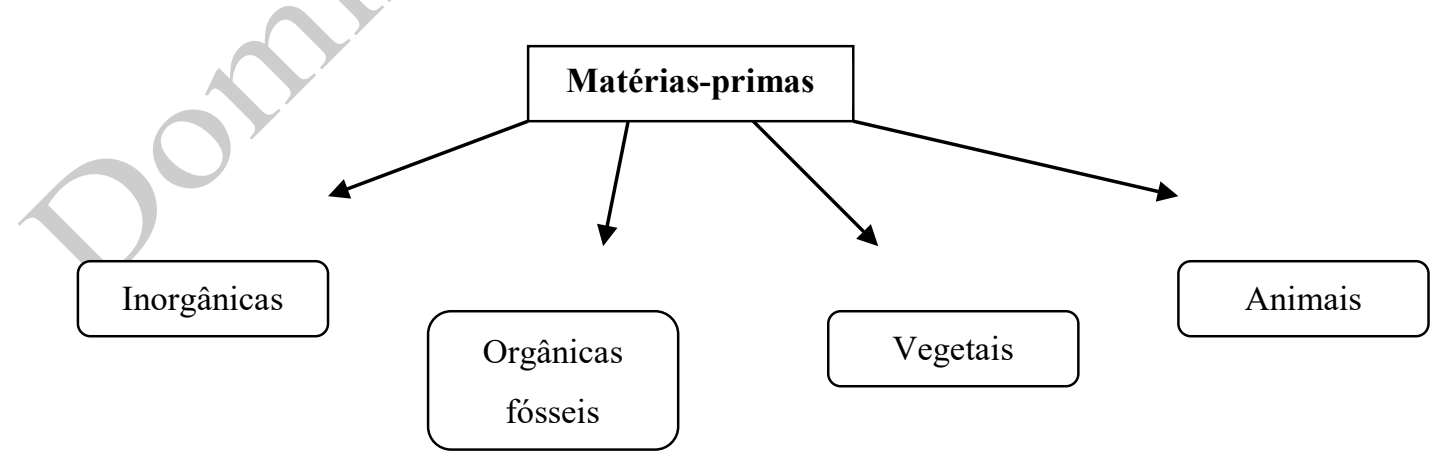

Figura 6. Elaboração do autor.

\footnotetext{
${ }^{1}$ DUTRA-DE-OLIVEIRA, J. E.; MARCHINI, J. S. Ciências nutricionais. São Paulo: Sarvier, 1998.

${ }^{2}$ BARUFFALDI, R; OLIVEIRA, M. N. Fundamentos de Tecnologia de alimentos. vol. 3. São Paulo: Atheneu, 1998.
} 
Os autores subdividem os alimentos, ainda, quanto à forma que são obtidos, em:

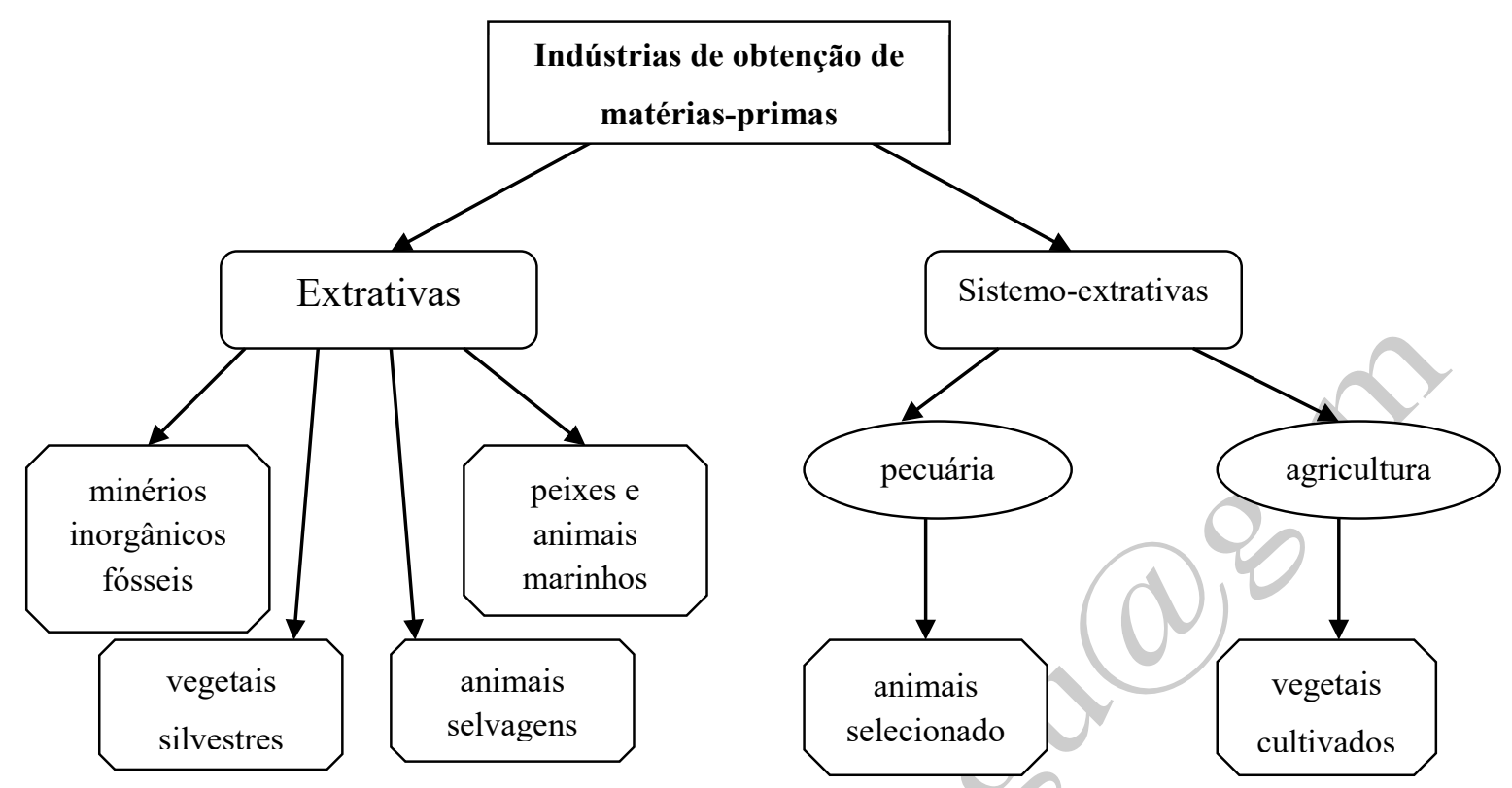

Figura 7. Elaboração do autor.

Porém, a divisão dos autores que mais se adequaria ao nosso propósito é aquela que chamam de "didática”:

É muito difícil tentar agrupar-se as matérias-primas da indústria alimentar de forma homogênea, não por falta de tentativas, mas, sim, pelas dificuldades que cercam o assunto. Existem agrupamentos que se baseiam nos aspectos botânico-morfológicos separando as matérias vegetais em suas porções: raízes, caules, folhas, frutos e sementes. Outros baseiam-se em aspectos legais e outros ainda nos mercadológicos. (...) Procurar-se-á, no entanto, aproximarse de um agrupamento que seja mais didático, onde são enfocados todos os parâmetros sem fugir dos que são usados na literatura, tomando-se como ponto de partida o da origem da matéria-prima (op. cit., p. 3, grifo nosso)

Com base na tabela apresentada pelos autores, elaboramos o esquema da Figura 8. 


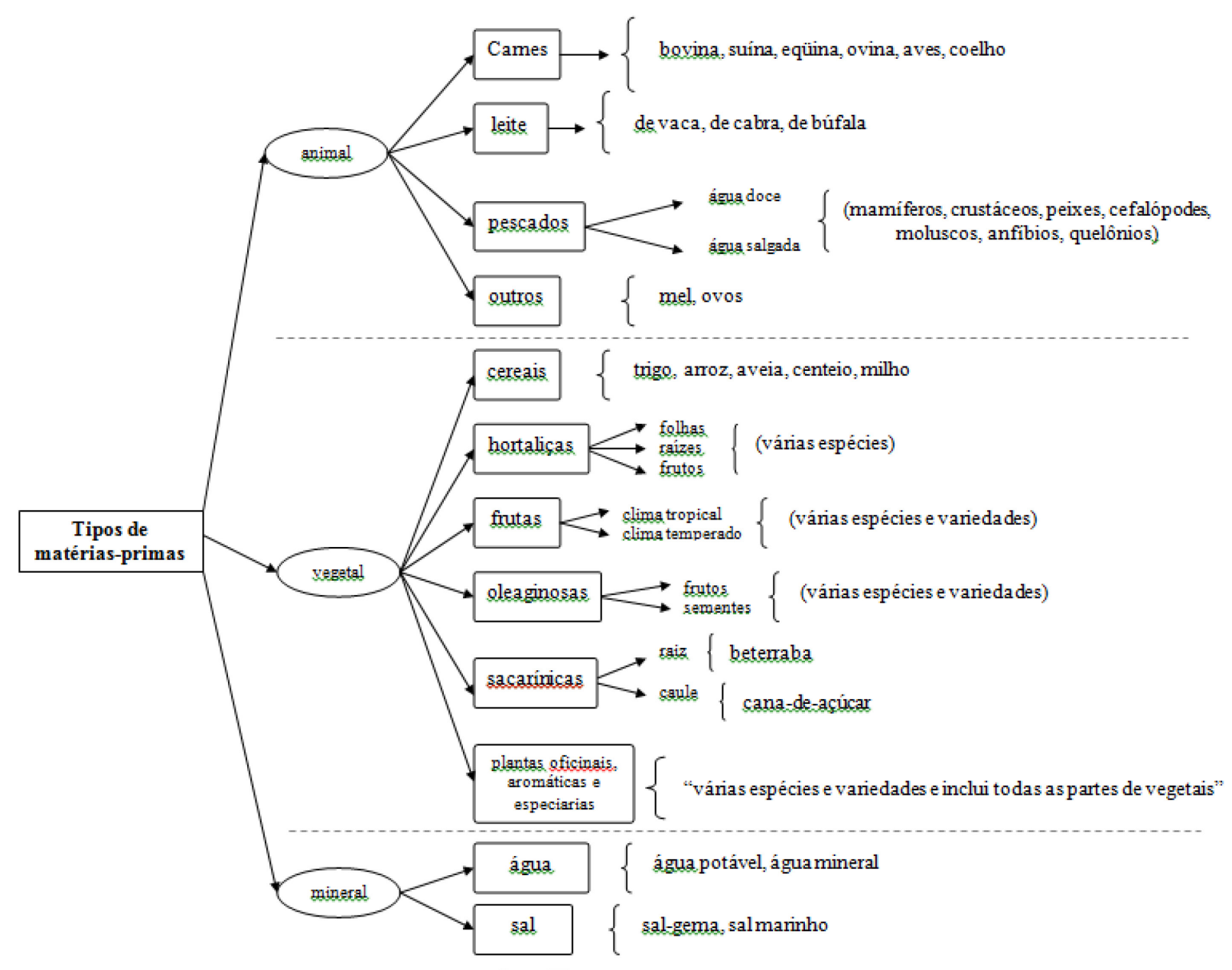

Figura 8. Elaboração do autor.

É possível observar no esquema da Figura 8 que, embora as especiarias e ervas recebam um tratamento individualizado (diferentemente da divisão apresentada pela obra citada anteriormente), o critério de categorização usado pelos autores não se justifica. Se, de fato, os autores pretendiam dividir os alimentos "tomando como ponto de partida o da origem da matéria-prima", cada uma das especiarias e/ou ervas deveriam estar agrupadas sob seus devidos grupos de "origem", conforme fossem eles cereais, hortaliças, oleaginosas, etc., como foi feito na categorização, um tanto confusa, representada no Quadro 1.

Assim, diante da profusão de perspectivas possíveis de se categorizar os alimentos, a nutrição, e dentro dela, a culinária, decidimos optar por um modelo de categorias e, primordialmente, uma árvore de domínio que, a nosso ver, dá conta, razoavelmente, dos critérios relevantes para a elaboração do glossário com base nas necessidades do tradutor e na natureza linguística suscitada por tal proposta de pesquisa. Tomamos como parâmetro a receita 
culinária e, com base em seu modelo prototípico, elaboramos nossa árvore de domínio (Vide Figura 10). A Figura 11 aplica esse modelo a uma receita ${ }^{3}$.

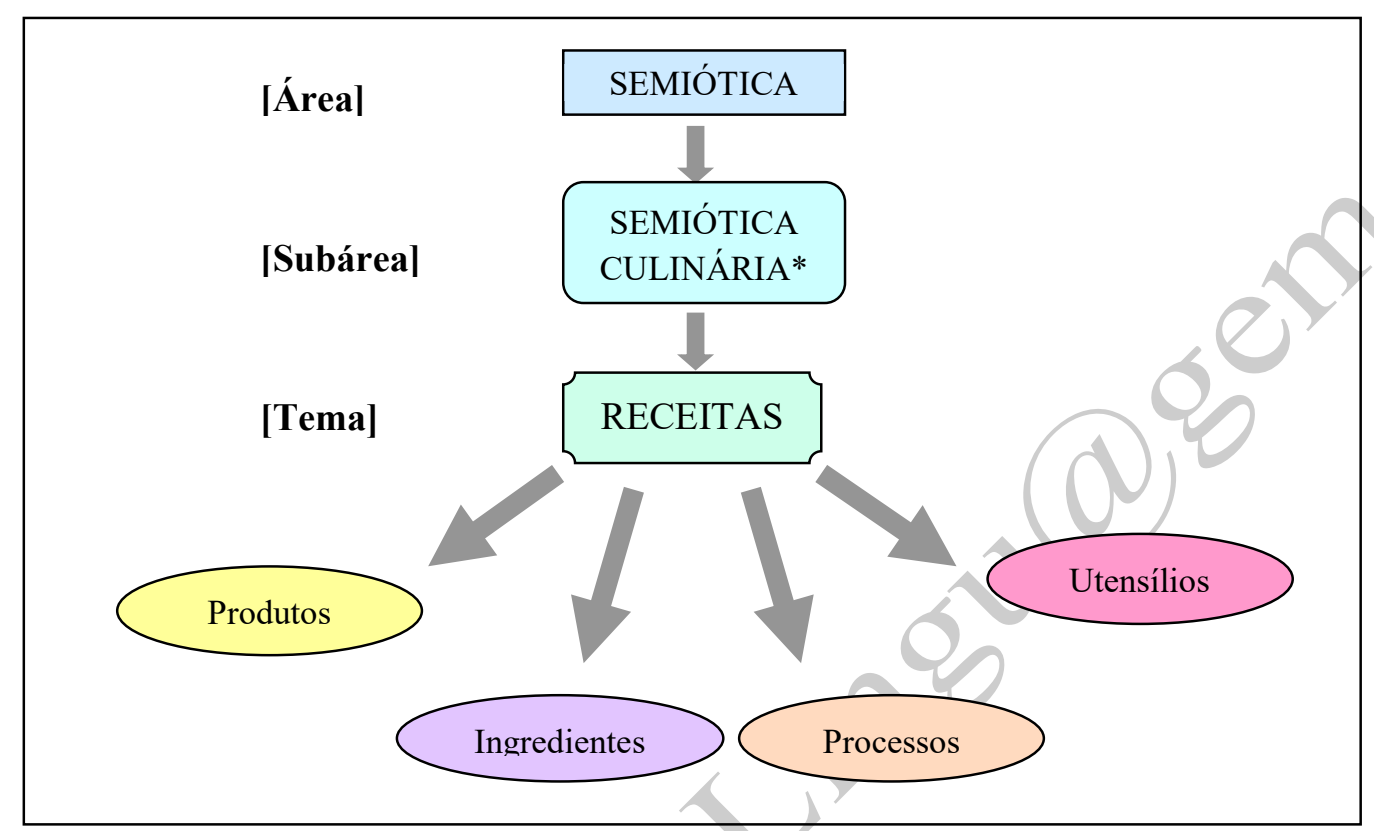

Figura 9. Elaboração do autor.

Dentre as quatro classes semânticas sugeridas acima: Produtos, Ingredientes, Processos e Utensílios, escolhemos trabalhar neste artigo com os Ingredientes, a começar por uma tentativa de definir suas subclasses semânticas.

\footnotetext{
${ }^{3}$ BUTLER, J. Um tesouro da cozinha clássica. Alberta, Canada: Creative Publishing Inc., 1998. (Observação: a receita apresentada é uma tradução do inglês e contém erros que não vamos discutir aqui.)
} 


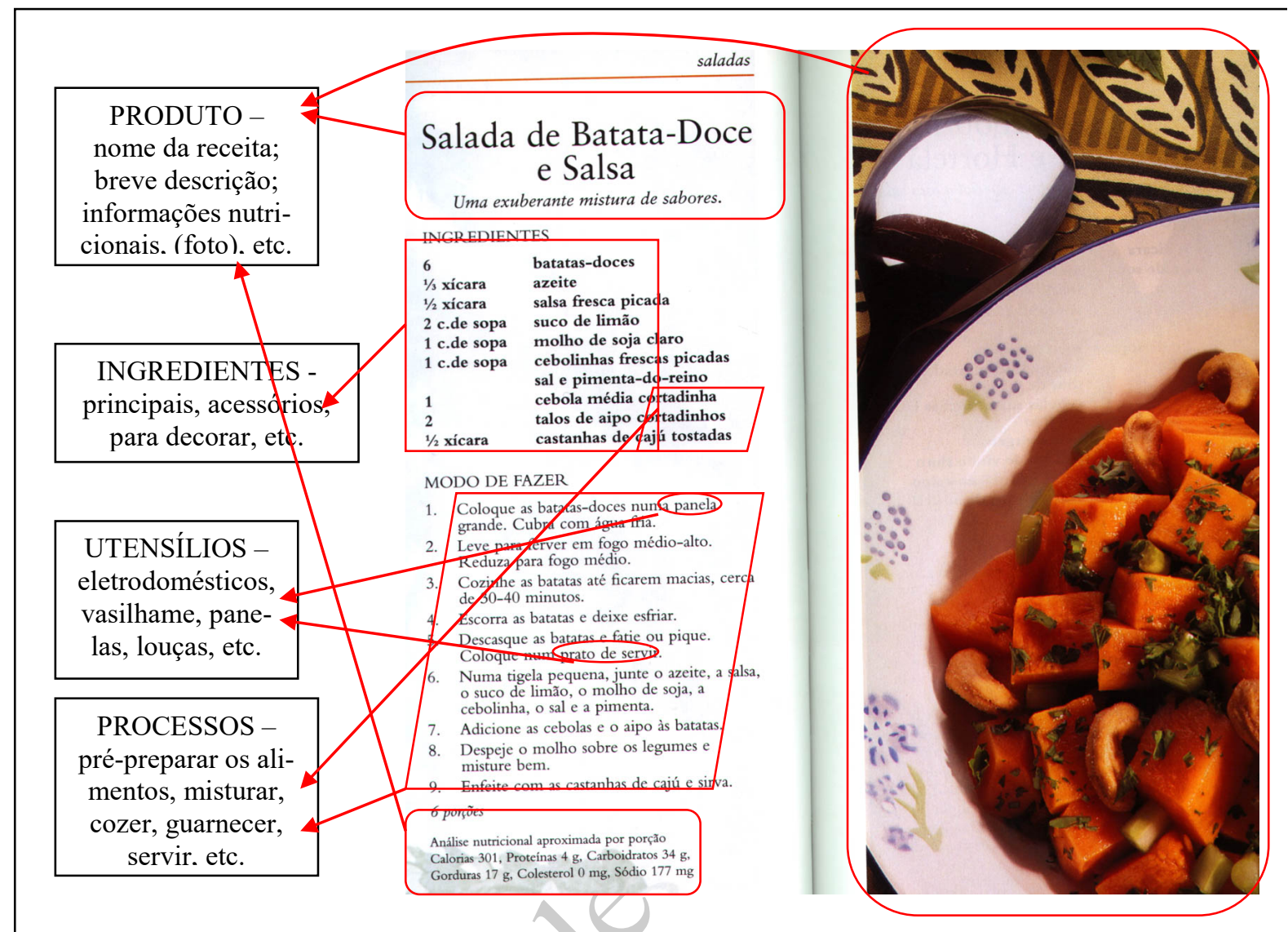

Figura 10. Elaboração do autor.

\subsection{Delimitando as subclasses semânticas dos Ingredientes}

Qualquer critério que usássemos para subdividir os Ingredientes, como já foi exemplificado anteriormente - confira Figuras 6, 7 e 8, seria falho. Vejamos, a seguir (Quadro 2), como um livro técnico da área, Ingredientes ${ }^{4}$, edição portuguesa revista e ampliada do original australiano Australasian ingredients, de 1997, divide os "ingredientes":

Quadro 2

\begin{tabular}{|c|c|}
\hline $\begin{array}{l}\text { ERVAS, TEMPEROS E SEMENTES } \\
\text { - } \quad \text { ervas } \\
\text { - } \quad \text { temperos e sementes } \\
\text { CREMES, ESSENNCIAS, INGREDIENTES PARA } \\
\text { MASSAS E CONSERVAS } \\
\text { - } \quad \text { mel, geleias e conservas } \\
\text { - } \quad \text { açúcar, xaropes e adoçantes } \\
\text { - } \quad \text { xaropes e essências doces } \\
\text { - } \quad \text { essências aromáticas e corantes }\end{array}$ & $\begin{array}{l}\text { - } \text { condimentos picantes } \\
\text { - } \quad \text { farinhas e aditivos } \\
\text { - } \quad \text { enfeites para bolos } \\
\text { - } \text { mostardas e pastas } \\
\text { - } \text { molhos } \\
\text { - } \quad \text { pickles, conservas e molhos picantes } \\
\text { ÓLEOS, MARGARINAS E GORDURAS } \\
\text { - } \quad \text { óleos e gorduras }\end{array}$ \\
\hline
\end{tabular}

\footnotetext{
${ }^{4}$ WERLE, L; COX, J. Ingredientes. Trad: Israel Jelin. Colónia: Könemann, 2000.
} 


\begin{tabular}{|c|c|}
\hline $\begin{array}{ll}\text { LACTICÍNIOS E PRODUTOS DA QUINTA } \\
\text { - } & \text { leite, natas e iogurte } \\
\text { - } & \text { manteiga e ovos } \\
\text { - } & \text { queijos } \\
\text { FRUTAS, LEGUMES E FUNGOS } \\
\text { - } & \text { legumes de folhas } \\
\text { - } & \text { batatas, raízes e tubérculos } \\
\text { - } & \text { rebentos } \\
\text { - } & \text { cucurbitáceas de verão e de inverno } \\
\text { - } & \text { bolbos } \\
\text { - } & \text { vagens e sementes } \\
\text { - } & \text { crucíferas } \\
\text { - } & \text { legumes de frutos } \\
\text { - } & \text { cogumelos e fungos } \\
\text { - } & \text { grãos } \\
\text { - } & \text { maçãs e pêras } \\
\text { - } & \text { citrinos } \\
\text { - } & \text { melões } \\
\text { - } & \text { bagas } \\
\text { - } & \text { frutas com caroço } \\
\text { - } & \text { uvas } \\
\text { - } & \text { frutas secas e nozes } \\
\text { PEIXES, MARISCOS FRESCOS E EM CONSERVA } \\
\text { - } & \text { peixes } \\
\text { - } & \text { mariscos } \\
\text { - } & \text { masigas e plantas aquáticas } \\
\end{array}$ & $\begin{array}{ll}\text { CARNES FRESCAS E PROCESSADAS } \\
\text { - } & \text { borrego } \\
\text { - } & \text { porco } \\
\text { - } & \text { vaca } \\
\text { - } & \text { vitela } \\
\text { - } & \text { miúdos } \\
\text { - } & \text { toucinho fumado e presunto } \\
\text { - } & \text { salsicharia continental } \\
\text { - } & \text { salame } \\
\text { - } & \text { carne de vaca em conserva } \\
\text { - } & \text { cabeça-de-achar, terrina e patê } \\
\text { AVES E CAÇA } \\
\text { - } & \text { frango } \\
\text { - } & \text { peru } \\
\text { - } & \text { ganso e pato } \\
\text { - } & \text { aves de caça } \\
\text { - } & \text { caça, lebre e coelho } \\
\text { - } & \text { veado } \\
\text { - } & \text { javali } \\
\text { BEBIDAS } \\
\text { - } & \text { café e outras bebidas } \\
\text { - } & \text { chá } \\
\text { COMIDAS DE TODO O MUNDO } \\
\text { - } \text { comida asiática } \\
\text { - } \text { comida mexicana } \\
\text { - } \text { especialidades } \\
\end{array}$ \\
\hline
\end{tabular}

Fonte: elaboração do autor.

Uma vista d'olhos permite-nos apontar vários problemas nesse modelo, ainda que não tenhamos o direito de julgá-lo quanto à sua adequação ao propósito a que se prestava - servir como "referência fotográfica" dos ingredientes disponíveis nos mercados e feiras pelo mundo afora. Mas poderíamos questionar tal modelo, por exemplo, no que se refere ao critério que serviu de base aos autores para separar "condimentos picantes" e "mostardas e pastas" das ERVAS, TEMPEROS E SEMENTES; ou ainda, os "miúdos" de seus animais de origem "borrego", "porco", "vaca e "vitela" - aliás, para o português brasileiro a distinção "porco / borrego" não é pertinente, nem "frutas de verão e inverno". O item "legumes de folhas" para nós é um paradoxo e "bolbos", "rebentos" e "bagas" não são parte de nosso vocabulário culinário corrente. Em suma, essa divisão proposta pelos autores parece não refletir a categorizações semânticas que buscamos para subdividir os Ingredientes, mas seria útil aproveitar algumas de suas proposições e criarmos um modelo mais resumido que permita-nos, 
finalmente, destacar dos Ingredientes nosso objeto específico de estudo - os Temperos.

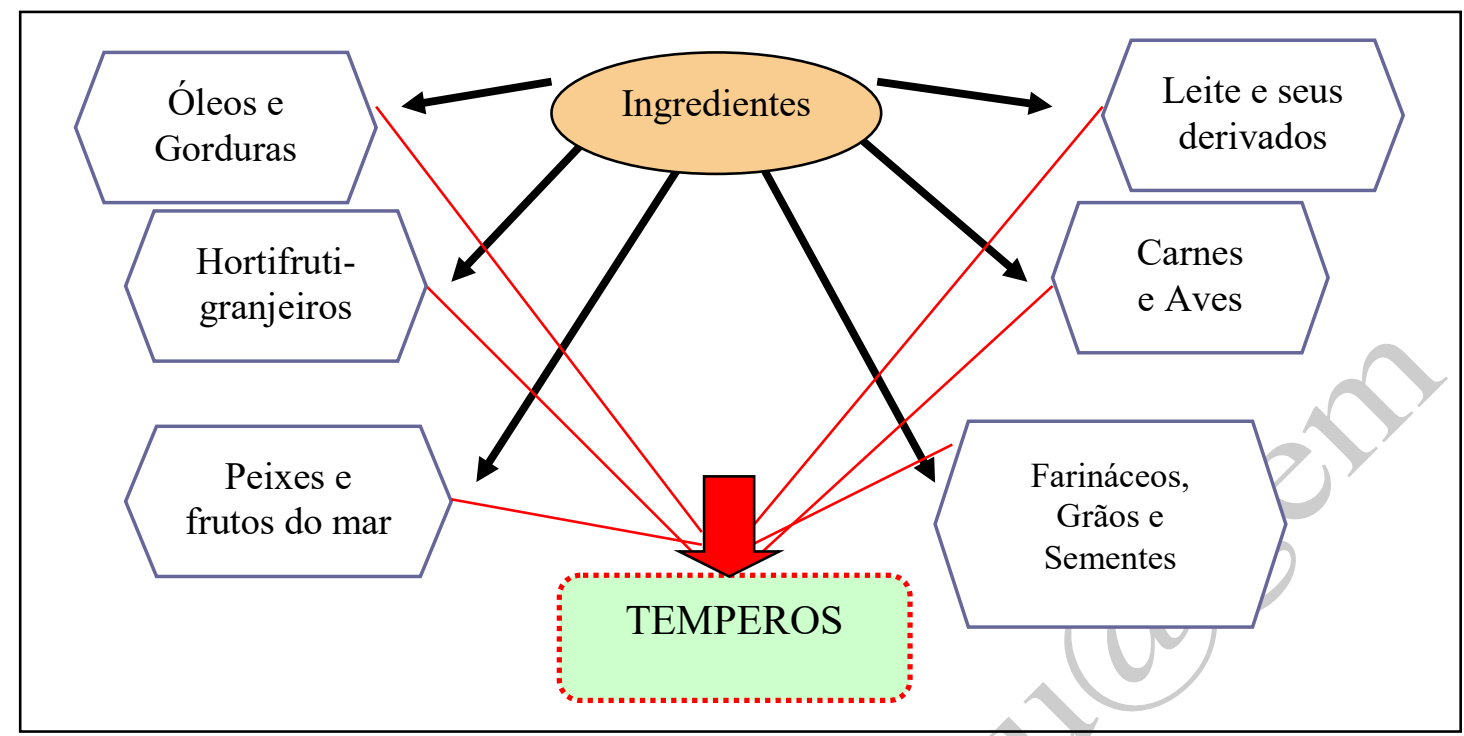

Figura 11: elaboração do autor.

Esse modelo, representado na Figura 11, procura levar em conta a natureza dos alimentos (origem, composição), mas nos concentraremos especificamente em seu uso para gerar a categoria Temperos. Assim, veremos que estes não constituem uma categoria à parte, uma vez que, pelo uso, qualquer ingrediente pode tornar-se um "tempero" - sementes (gergelim); carnes (caldo, em cubos); peixes (molho de ostras), etc. No entanto, há alguns alimentos que são mais "representativos" dos Temperos, ou seja, são mais frequentemente usados como Tempero.

Tomemos o caso, por exemplo, do "manjericão" - uma Erva usada frequentemente como Tempero - na receita do tradicional molho italiano Pesto, o "manjericão" torna-se ingrediente principal, juntamente com o "azeite de oliva" e os dois tipos de queijo: "parmesão" e "pecorino". Já o sal grosso e o alho é que são usados como tempero, ou seja, seu acréscimo é em quantidade reduzida e sua adição ou não vai alterar o sabor do molho, ainda que seja uma complementação do prato. Visto de outra forma, não é possível, por exemplo, omitirmos o "macarrão" de uma "macarronada", da mesma forma que se omitimos "manjericão" do "Molho Pesto", não temos "Molho Pesto" - isso significa que é devido à função do ingrediente na receita que se poderá determinar sua categoria.

No exemplo acima podemos vislumbrar (em itálico) alguns dos semas que nos permitirão diferençar os Temperos dos demais Ingredientes - semas esses que, como 
procuramos demonstrar, estão mais relacionados ao 'uso' do ingrediente, que pode ser apreendido na receita, que à sua 'natureza' (origem, parte da planta, etc.); ou, nas palavras de Barbosa (2002): "é na instância discursiva que se produz a cognição e a semiose, se instaura a conceptualização de um 'fato', se engendra um conceito e sua manifestação linguística". No caso do presente trabalho, é com base no uso discursivo dos termos classificáveis como Temperos que pautaremos nossa observação.

Passemos, portanto, a uma tentativa de conceituar alguns dos termos-base desse domínio partindo de definições encontradas em dois tipos de obras lexicográficas e de uma publicação técnica da área.

\subsection{Temperos: definições $x$ conceitos}

Para que possamos proceder à tarefa de conceituar "Tempero", avaliamos a definição desse e de outros seis termos: "condimento", "especiaria", "erva(s)", "flavorizante", "aromatizante" e "corante" em quatro obras lexicográficas e terminográficas distintas, a saber: os dicionários de língua Houaiss ${ }^{5}$ e Aurélio $^{6}$, os vocabulários: Pequeno dicionário de gastronomia, de Maria Lúcia Gomensoro ${ }^{7}$ e Dicionário Prático de Culinária $^{8}$, tradução do original inglês, de 1991, Cooking and kitchen skills; e o livro O guia das especiarias, também tradução (portuguesa) do original em língua inglesa de Richard Craze ${ }^{9}$.

\section{Resultados}

As definições encontradas nas referidas obras permitem-nos fazer algumas inferências:

a) Para Houaiss, Aurélio e Gomensoro, os termos "tempero" e "condimento" estão em relação de homossemia parcial, com um alto grau de transitividade (Figura 12), isto é, os dois conceitos partilham certos semas, mas não todos, estabelecendo assim uma relação de quasi-sinonímia.

\footnotetext{
${ }^{5}$ HOUAISS, A. Dicionário eletrônico Houaiss da língua portuguesa. Rio de Janeiro: Objetiva. Versão 1.0. 1 [CD-ROM]. 2001.

${ }^{6}$ FERREIRA, Aurélio Buarque de Holanda. Novo Aurélio Século XXI: o dicionário da língua portuguesa. Rio de Janeiro: Nova Fronteira, 1999.

${ }^{7}$ GOMEnSORO, M. L. Pequeno Dicionário de Gastronomia. Rio de Janeiro: Editora Objetiva Ltda, 1999)

8 JONES, B. Dicionário Prático de Culinária. Trad. de Maria Emília de Oliveira. São Paulo: Companhia Melhoramentos, 1996.

${ }^{9}$ CRAZE, R. O guia das especiarias. Guia do conhecedor. Trad.: Jorge Pinheiro Valente. Portugal: Centralivros Lda., 1998.
} 
Já para Jones, os termos estão em relação de inclusão (Figura 13), ou seja, "condimento" mantém com "tempero" uma relação de hiponímia:

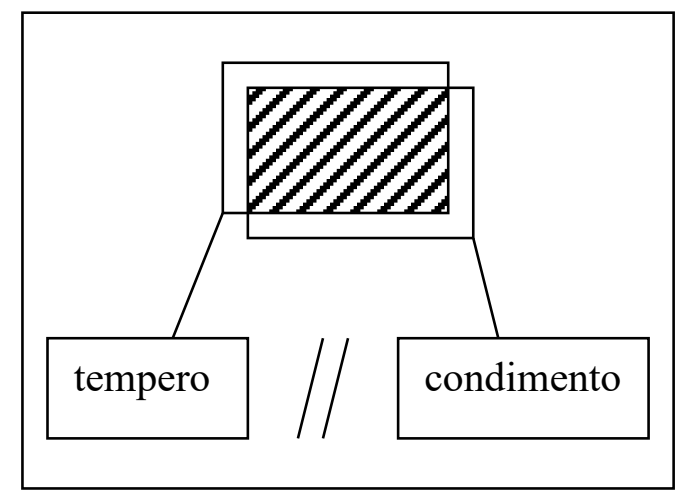

Figura 12

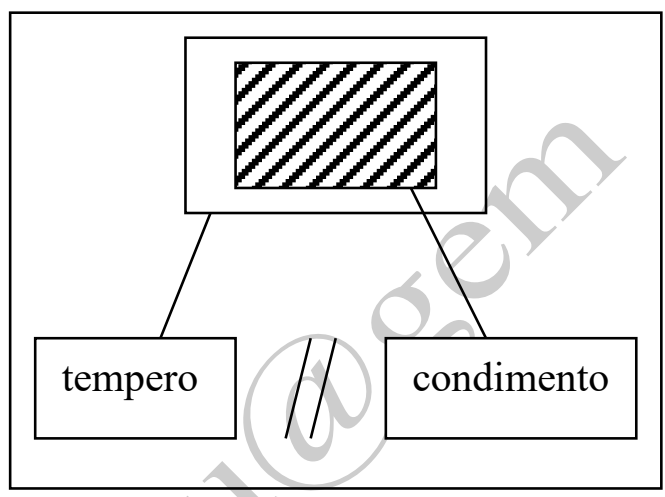

Figura 13

b) Gomensoro privilegia o termo "tempero", uma vez que a definição de "condimento" nos remete a ele: "condimento. ver Tempero". Mas, não é possível inferir, na obra, o motivo que leva a autora a privilegiar um termo em detrimento do outro.

c) quanto aos semas, pudemos observar recorrências da seguinte ordem ${ }^{10}$ :

- tempero: $\{[$ substância] [ingrediente] $\}\{$ [condimentar] [adicionar a] - [iguaria] [comida] [alimento]\} \{[realçar] [melhorar] [intensificar] [complementar] - [sabor] [aroma] $\}\{[$ forte] [marcante] - [pequenas quantidades]\}

- condimento: $\{[$ substância] [ingrediente] [tempero] $\} \quad\{[$ vegetal] [sal] [pimenta] [especiaria] $\}$ [acrescentar ao] [adicionar ao] - [alimento] [prato]\} \{[emprestar] [realçar] [complementar] - [sabor] [paladar] $\}\{$ [sabor acentuado] [pequenas quantidades]\}

- especiaria: $\{[$ ervas] [planta] [vegetal] [tempero] $\}\{[$ condimentar] [dar] - [sabor] [aroma] $\}$ $\{[$ parcimônia] $\}\{[$ história] [terras distantes] [tesouro] [exótico] [navegadores] $\}\{[$ paladar exigente] [alta cotação] [caro] [valer]\}

- $\operatorname{erva(s):~}\{[$ planta] [erva $\}\{[$ realçar] [complementação] - [sabor] [aroma]\} \{[forte] [sabor acentuado] [superposição do sabor] $\}\{$ usar com cautela] [empregar com conhecimento]

\footnotetext{
${ }^{10} \mathrm{Na}$ notação usada a seguir, para cada lexema especializado (grafado em negrito), apresentamos os sememas, isto é, os conteúdos semânticos identificados nas obras consultadas (entre chaves), que, por sua vez, são compostos por semas (entre colchetes), que são a unidade mínima de significação.
} 
[parcimônia] [sem que sabor predomine]\}

- flavorizante: $\{[$ confere] [intensifica] - [sabor] [odor] [aroma] [fragrância]\}

- aromatizante: $\{[$ substância] [ingrediente] $\}\{$ [alterar perfume] [perfumar] [condimentar] [prato] [alimento]\}

- corante: $\{[$ intensificar] [melhorar] - [cor] [aparência]\}

d) para as obras que tratam do termo no nível das Normas (COSERIU, 1967), a saber, Gomensoro, Jones e Craze, o termo "erva" não existe senão no plural: "ervas" - o que parece já ser um recorte, por meio do perfil sintático-morfológico adquirido pelo mesmo, do estatuto do termo no nível do Sistema - em que "erva" tem uma carga semântica muito genérica, e portanto ampla, como se pode observar pelas definições dos dicionários de língua geral Houaiss e Aurélio.

e) um outro aspecto enfatizado apenas pelos vocabulários é o paradigma que define o uso prático do termo na área: os semas do tipo "é preciso empregá-las com conhecimento, com parcimônia e sem grandes misturas" ou "As ervas frescas são encontradas em supermercados, feiras (...)" - esse tipo de sema não ocorreu nas obras que descrevem o Sistema.

\section{Considerações finais}

Com base nos semas e observações apresentados acima e na subdivisão proposta pelo livro Ingredientes (Cf. Figura 11), podemos definir algumas subclasses semânticas de "Temperos", considerando, ainda, a distinção que fizemos no item 3 entre ingredientes "principais" e "acessórios" - o que nos permitiria incluir aqui, ainda que esse constructo teórico não represente a realidade da Norma, os açúcares e substâncias adoçantes em geral ${ }^{11}$ como ingrediente "acessórios", como mostra o Quadro 3.

\footnotetext{
${ }^{11}$ Seria necessária uma ampla discussão aqui para que nos fosse permitido fazer tal inclusão. No entanto, devido à exiguidade do tempo e espaço impostos pela natureza do presente trabalho, preferimos incluir a categoria dos açúcares ainda que não vamos discuti-la aqui, pois acreditamos que omiti-la seria menos proveitoso do que mencioná-la sem a devida discussão que demanda. Algumas questões sem resposta nos obrigam a repensar, futuramente, o estatuto dessas substâncias dentro desse campo semântico dos temperos / condimentos, por exemplo: O que é o açúcar? É um tempero? Se digo que não é um tempero, porque "tempero" refere-se a coisas salgadas, o que dizer das especiarias, são "salgadas" ou "doces? Tanto a canela quanto a pimenta são especiarias? Se é uma característica das especiarias serem picantes, a baunilha seria uma especiaria ou um flavorizante?
} 
Quadro 3.

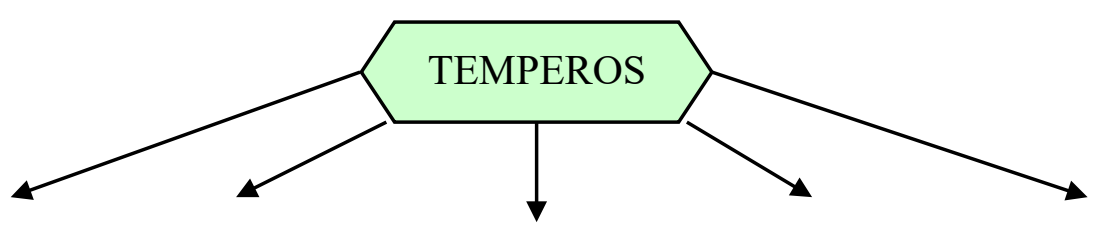

\begin{tabular}{|c|c|c|c|c|}
\hline $\begin{aligned} & \text { ERVAS } \\
+ & \text { [TEMPERO }] \\
+ & {[\text { FRESCA }] } \\
+ & \text { [FOLHAS }] \\
+ & {[\text { BULBO }] }\end{aligned}$ & \begin{tabular}{l}
\multicolumn{1}{c}{ ESPECIARIAS } \\
$+[$ TEMPERO $]$ \\
$+[$ CONDIMENTO $]$ \\
$+[$ ERVA $]+[$ SECA $]$ \\
$+[$ RAIZ $]+[$ FRUTO $]$ \\
$+[$ CASCA $]$
\end{tabular} & $\begin{array}{c}\text { FLAVORIZANTES } \\
\text { ESSÊNCIAS E } \\
\text { CORANTES } \\
+/-[\text { ARTIFICIAL] } \\
+/-[\text { MODIFICADO] }\end{array}$ & \begin{tabular}{|l}
\multicolumn{1}{c}{ AÇÚCARES E } \\
XAROPES \\
+ [DOCE]
\end{tabular} & \begin{aligned} & \multicolumn{1}{c}{ INDUSTRIA- } \\
& \multicolumn{1}{c}{ LIZADOS } \\
&+${[$ COMPOSTO $] } \\
&+ {[$ PROCESSADO $] } \\
&- {[$ NATURAL $] }\end{aligned}$ \\
\hline melissa & junípero & água de rosas & rapadura & molho de soja \\
\hline cerefólio & macis & cenoura em pó & melado & tahine \\
\hline salsa-crespa & anis estrelado & baunilha & "karo" & molho inglês \\
\hline erva-doce & alcaravia & tinta de lula & $\begin{array}{l}\text { açúcar de } \\
\text { confeiteiro }\end{array}$ & $\begin{array}{l}\text { tablete de caldo de } \\
\text { carne }\end{array}$ \\
\hline segurelha & feno-grego & "aji-no-moto" & açúcar demerara & catchup \\
\hline
\end{tabular}

Fonte: Elaboração do autor.

Um aspecto que precisaria ser mais bem examinado são as zonas fluidas de transição que determinam que um dado ingrediente seja "erva", "condimento" ou "especiaria". A partir daí seria possível desenhar um mapa conceptual dos Temperos, ou "ingredientes mais comumente usados como acessórios" que tivesse categorias de núcleo sêmico nítido, em torno do qual os diversos temperos se distribuíssem a maior ou menor distância do centro, conforme seja um melhor ou pior representante daquele conjunto de semas caracterizadores. Assim, em vez da categoria clássica estanque, comumente usada para separar os semas genéricos dos específicos (Figura 14), em que cada tempero é necessariamente considerado como representante ou não uma dada definição, teríamos uma estrutura de periferia permeável, conforme ilustrado na Figura 15: 


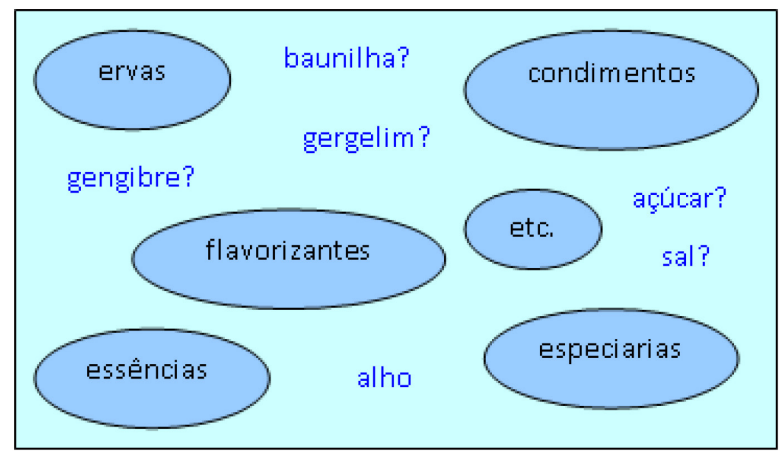

Figura 14. Fonte: elaboração do autor.

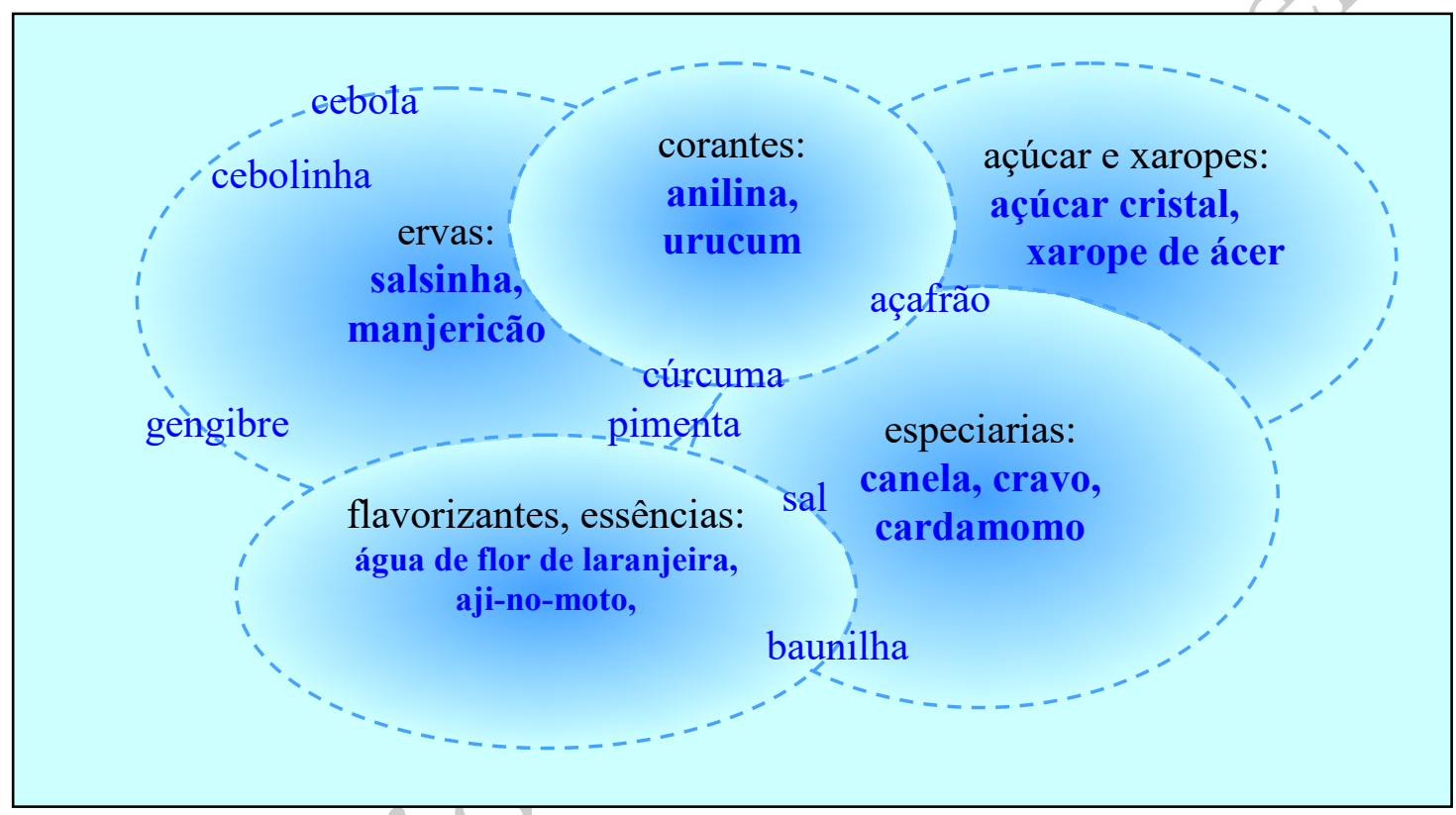

Figura 15. Fonte: elaboração do autor.

É preciso ressaltar a importância de proceder a uma análise sêmica detalhada dos termos simples e complexos antes que se possa determinar com precisão a quais classes e subclasses semânticas cada Ingrediente pertence. Pode-se esperar que, devido à enorme carga cultural dos termos relacionados à alimentação em geral, os semas distintivos em uma língua não vão necessariamente ser distintivos ou mesmo existir em outras línguas - do que resultam diferenças conceituais do maior interesse para a prática tradutória e terminológica.

As discussões aqui apresentadas buscam fazer uma pequena contribuição para a consolidação dessa nova área técnica - a Culinária -, bem como reafirmar a necessidade de se produzir obras lexicográficas e terminográficas cujo modelo tecno-formal e corpus de estudo levem em conta o público-alvo a que se destinam. 


\section{Referências bibliográficas}

ALMEIDA, G. M. B. A problemática epistemológica em terminologia: relações entre conceitos. ALFA - Revista da Universidade Estadual Paulista, São Paulo, vol. 42 (número especial), 1998.

AUBERT, F. H. Problemas e urgências na interrelação terminologia / tradução. ALFA Revista da Universidade Estadual Paulista, São Paulo, vol. 36, 1992.

Introdução à metodologia da pesquisa terminológica bilíngue. Cadernos de Terminologia - Revista do CITRAT/FFLCH/USP, São Paulo, no. 2, 1996.

BARBOSA, M. A. Lexicologia, lexicografia, terminologia, terminografia: identidade científica, objeto, método, campos de atuação". Anais do II Simpósio Latino-americano de Terminologia e I Encontro Brasileiro de Terminologia Técnico-científica. Brasília: SCT, CNPq, IBICT, 1990.

. Lexicologia, lexicografia, terminologia, terminografia: identidade científica, objeto, métodos, campos de atuação. Anais do II Simpósio Latino-Americano de Terminologia. I Encontro Brasileiro de Terminologia Técnico-Científica. Brasília: União Latina, CNPq, IBICT, 1992, p. 152-158.

Dicionário, Vocabulário e Glossário: concepções. In: ALVES, I. M. (org) Constituição da normalização terminológica no Brasil. Cadernos de terminologia- Revista do CITRAT/FFLCH/USP, São Paulo, vol. 1, 1996.

. Relações de significação nas unidades léxicas. Anais do I Encontro Nacional do GT de Lexicologia, Lexicografia e Terminologia da ANPOLL. Rio de Janeiro: ANPOLL, 1998.

Terminologização, vocabularização, cientificidade, banalização: relações. Acta semiotica et linguistica, São Paulo: Plêiade, V. 7, 1998, p. 25-44.

Campo conceitual e campo lexical dos termos globalização e mundialização: relações. Revista brasileira de linguística, São Paulo: Plêiade, V. 19, 1999, n.1, p. 29-45.

. A construção do Conceito nos discursos técnico-científicos, nos discursos literários e nos discursos sociais não-literários. Revista Brasileira de Linguística. São Paulo: Plêiade, 2002 .

BARTHES, R. Elementos de Semiologia. São Paulo: Cultrix, 1971.

BORBA, F. S. e LONGO, B. N. O. Ciência \& arte \& técnica: a delimitação dos sentidos num dicionário. ALFA - Revista da Universidade Estadual Paulista, São Paulo, vol. 40, 1996.

COSERIU, E. Teoria del lenguaje y linguística general. Madrid: Gredos, 1967.

Lições de linguística geral. Rio de Janeiro: Ao Livro Técnico, 1980. 
DESMET, I. Princípios teóricos da terminologia: especificidade da noenímia. Terminologia Revista da Ass. de Terminologia Portuguesa, Lisboa, no. 1, abril de 1990.

DUBOIS, D. Sémantique et cognition. Catégories, prototypes, typicalité. Paris: CNRS, 1991.

DUBUC, R. Manuel pratique de terminologie. Québec: Biblithèque Nationale, 1985.

GENOUVRIER, E.; PEYTARD, J. Linguística e ensino do português. Coimbra: Almedina, 1974.

HJELMSLEV, L. Prolégomènes à une théorie du langage. Paris: Minuit, 1966.

JACKOBSON, R. Linguística e comunicação. São Paulo: Cultrix, 1969.

LYONS, J. Semantics. Cambridge: Cambridge University Press, 1977.

MÜLLER, Ch. Principes et méthodes de statistique lexicale. Paris: Champion, 1992.

OLIVEIRA, A. M. P. e IZQUERDO, A. N. (Orgs.) As ciências do léxico. Campo Grande: Ed. UFMS, 1998.

PAIS, C.T. Ensaios semiótico- linguísticos. São Paulo: Global, 1984.

. O percurso gerativo da enunciação: produtividade léxica e discursiva. Confluência -

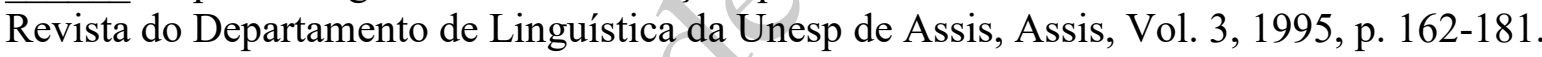

Da semântica cognitiva à semiótica das culturas. Anais do IX Encontro Nacional da ANPOLL. João Pessoa: ANPOLL, 1995, p. 1325-1336.

- Conceptualização, denominação, designação: relações. Revista Brasileira de Linguística, São Paulo: Plêiade, vol. 9, 1997, p. 221-240.

POTTIER, B. Linguística geral: Teoria e descrição. Rio de Janeiro: Presença, 1978.

REY, A. La terminologie: noms et notions. Paris: PUF, 1979.

VILELA, M. Definição nos dicionários de português. Porto: Asa, 1983. 